\title{
SIGNIFICANCE OF FISCAL POLICY FOR ECONOMIC DEVELOPMENT AND AGRICULTURE
}

\author{
Petar Veselinović ${ }^{1}$, Miloš Dimitrijević ${ }^{2}$, Milan Kostić ${ }^{3}$ \\ *Corresponding author E-mail: mdimitrijevic@kg.ac.rs
}

A R T I C L E I N F O
Original Article
Received: 17 April 2019
Accepted: 28 May 2019
doi:10.5937/ekoPolj1902357V
UDC 336.02:[330.34+338.43.01

Keywords:

fiscal policy, economic development, fiscal policy as part of economic policy, agricultural policy, global economic crisis

JEL: C12, E62, H60, I31, O23, Q18

\section{A B S T R A C T}

With the latest global economic crisis (2007-2009) the importance of fiscal policy as a part of economic policy is growing. Its significance extends from the experience of the Great Depression of the 1930s. In this paper, with the help of the ARIMA model, the influence of fiscal policy instruments on macroeconomic fiscal indicators and some selected indicators of economic development in the context of countries of Southeast Europe have been explored. Friedman's test has shown that the countries have not yet recovered from the global economic crisis. The results shows that fiscal policy can act on the individual's standard of living, but only responsible implementation will have the same effect on public finances and the overall sustainable development of a country. Also, fiscal policy is an important measure of agricultural policy and is increasingly being used as a directional development factor.

(C) 2019 EA. All rights reserved.

\section{Introduction}

In the modern economy, which is burdened with numerous problems which has an impact on economic development and increase of social inequality, great attention is paid to the interaction of monetary and fiscal policy. The public economy is a vital system of production and delivery that produces scores of products: goods, services, benefits and innovations (Sekera, 2018).

State interventionism imposed even in traditionally highly neoliberal economies, took

1 Petar Veselinović, Ph.D, Full Professor, Dept. of General Economics and Economic Development, University of Kragujevac - Faculty of Economics, Liceja Knezevine Srbije 3, 34000 Kragujevac, Serbia. Phone:+381 34303 569. E-mail: pveselinovic@kg.ac.rs. ORCID ID (https://orcid.org/0000-0002-2765-1730)

2 Miloš Dimitrijević, Ms.C, Research trainee, Dept. of General Economics and Economic Development, University of Kragujevac - Faculty of Economics, Liceja Knezevine Srbije 3, 34000 Kragujevac, Serbia. Phone:+381 34303 562. E-mail: mdimitrijevic@kg.ac.rs. ORCID ID (https://orcid.org/0000-0001-9253-8876)

3 Milan Kostić, MSc in Economics, University of Kragujevac - Faculty of Economics, Liceja Knezevine Srbije 3, 34000 Kragujevac, Serbia. Phone:+381 66387484, E-mail: kosticmilan@live.com

http://ea.bg.ac.rs 
on various forms (Allen et al., 2015, Caprio et al., 2014, Classenes et al., 2014). ). In contemporary economic conditions and with the emergence of economic integration, the issue of budget deficit is one of the main problems of public finances (Despotović, Durkalić, 2017). Fiscal policy is a part of economic policy that through the management of public revenues and public expenditures seeks to achieve certain macroeconomic and microeconomic goals (Fabris, Pejović, 2013). Fiscal policy is an important measure of agrarian policy, and considering that at the time of state formation agriculture was the only activity, tax had a fiscal character. The tax conditions are determined by the needs of the state budget and direction of development (Ristić, 2015). Agricultural policy, as an integral part of economic policy, is implemented through state programs in the field of agriculture (Ristić, 2015) that play a significant role in the economic development of each country.

In the case of Serbia, if the agricultural household is not in the VAT system, it's the taxpayer on the Personal Income tax on the income from agriculture and forestry on the basis of cadastral income (Tica et al., 2011), which has a function to raise money for the budget and influence development through stimulating activities in agriculture and the village (Ristić, 2015). If the farmers make the sale of agricultural and forest products or agricultural services to taxpayers, the taxpayer is obliged to charge a VAT fee in the amount of $8 \%$ on the value of goods and services received and pay off to farmers in cash. A farmer whose total turnover of goods and services in the previous 12 months doesn't exceed 8,000,000 RSD doesn't charge VAT for executed turnover of goods and services. If a farmer is recorded for VAT by submitting a registration application, a VAT rate of $20 \%$ is prescribed, except for certain products, such as milk, bread, sugar, sunflower oil etc., where the rate is 10\% (Value Added Taxual Law according to "Official Gazette RS ", no. 30/2018). VAT is a modern method of collecting taxes that is necessary to create a stable economic system (Ristić, 2015). Farmer in the VAT system, unlike others, has the right to refuses the tax paid when purchasing agricultural machinery, fertilizers, reproduction seeds, planting stock, breeding cattle and etc. (Vujičić, Ristić, 2006). Agricultural household in the VAT system is allowed to reduce the tax base for tax incentives (Tica et al., 2011). In addition, corporate income tax rate of $15 \%$ is proportional, with many options available for reduction of corporate income tax burden - for example, investment tax incentive and tax loss carryforward. (Corporate Profit Taxual Law according to "Official Gazette RS “, no. 95/2018).

The efficiency of the market is very difficult to achieve because of unanticipated policies (Stiglic 2013) and influence of foreign companies on government (Lazonick, 2014, Hamilton, Hepburn, 2017). That is why a state is required to take care of citizens (Bryne, Ruane, 2017). The dilemmas about the degree of state intervention in the field of production are no more recent. Free market and mandatory control have long been the focus of theoretical discussions. Free market means the elimination of all directed programs that directly affect the supply of agricultural products. However, this doesn't eliminate other forms of government intervention that indirectly affect the market of certain commodities (Vujičić, Ristić, 2006). Agricultural products are specific in 
relation to others, and therefore, it's impossible to leave this area in the domain of market laws, so the state should specifically apply to this economic branch of vital importance for economic development (Ristić, 2015), which is reflected in the resource management and the role of management in agriculture, which includes the entire complex of decisions of the state related to the economy of the country as whole. (Ristić, 2015). Also, food industry is very important for future economic activity of the whole country (Domanović, Vujičić, Ristić, 2018). The concept of sustainable development, which represents harmonious relationship between econmy and environment, is very important in agriculture because the constant aspiration for the economic growth puts a strong pressure on the environment (Aničić et al., 2019).

Some authors deal with linking economic growth to fiscal policy (Moreno-Dodson, 2013) and some questioned linked budgetary parameters (public revenue and expenditure) with the rate of economic growth expressed in GDP through Laffer's production and fiscal curve, Armey-Rahn curve (Balatsky, Ekimova, 2012) and concluded that growth is positively related to good fiscal performance. Authors who have dealt with modern theories of economic growth and welfare are exploring policies to eradicate poverty (Acemoglu, 2006, Aghion, Howitt, 2009, Yifu Lin, 2012), as well as the impact of public expenditure and tax on growth (Bleaney, Gemmel, Kneller, 2001).

Different factors in economic literature (Stanković, 2006) encountere that fiscal policy measures can be used to control aggregate demand in the economy. Coordination of fiscal and monetary policy is important, but the state intervene in the economy primarily by fiscal policy which responsible for not having unemployment and falling living standards (Vukadin and Labus, 2012; Singh et al., 2018; Tylor, 2018; Koppel and Kolencik, 2018; Hyers and Kovacova, 2018; Popescu et al, 2018). In accordance with that, it is important to have independent central bank (Thiele, 2018). It is clear that the issues related to unemployment might affect business environment, not only the consumers and human resources (Furtula, Durkalić, Simionescu, 2018). It's necessary to compare burden of tax financing and borrowing (Rozen, Gejer, 2009) in the context of the analysis of the possible impact of the budget deficit and public debt on economic growth. Servicing obligations on the basis of the budget deficit can lead to an increase in taxes and a reduction in available income, which would as a result have a fiscal policy effect on the decline in living standards and the rate of economic growth through the reduction of real GDP (Despotović, 2015). This was particularly reflected during the global economic crisis when many economies didn't have space for the implementation of a fiscal expansion (Praščević, 2012). Fluctuations in developing countries which follows procyclical policies are greater than in developed countries which follows a countercyclical monetary and fiscal policy, that increases the advantage of developed countries (Stiglic, 2013). The implications of fiscal policy on social welfare require a model of social policy that links fiscal policy instruments to outcomes that include the growth model and the way in which it shapes social welfare (Moreno-Dodson, 2013).

There is no measure that can cover all the complexity of what is happening in modern society. The United Nations Development Program has designed a broader measure that http://ea.bg.ac.rs 
includes education, health and income (Stiglic, 2013), it's Human Development Index. The unemployed faced the highest risk of poverty and the accent for its reduction is put on a healthier economic development (Todaro, Smith, 2006). The reason for research period (2000-2016) is that the transition countries we are looking at with more serious reforms started in the late 1990s due to war events in the Balkans and other factors that led to the delay. For market fundamentalism, the day when the Liman braders fell (September 15, 2008) is the same like fall of the Berlin Wall was for communism (Stiglic, 2013), due to which attention was paid to the period of global economic crisis and after it. Although the first signs of the recovery of the world economy were registered at the end of 2009, this still does not mean that the world has escaped the crisis (Kovačević, 2010).

The subject of this paper is to identify the impact of key fiscal policy instruments available to create macroeconomic stability which contribute to growth of agricultural sector and overall economic development. In this context, the aim of the work is to focus on how the application of different fiscal policy instruments reflects on economic development.

The starting point of the conceptual framework for empirical research in this paper consists of fiscal policy instruments, taxation and public expenditure whose role is to reflect the nature of fiscal policy to create macroeconomic stability and economic development in the Southeast Europe during the period 2000-2016.

The basic hypothesis on which this work is based relates to the fact that changes in fiscal policy instruments affect the economic growth and welfare of society. Individual hypotheses, whose validity should be checked by empirical research, are formed by stratifying the basic hypothesis:

X1: Tax revenues and public expenditure, like fiscal instruments, affects on the budget deficit/surplus and public debt.

X2: Tax revenues and public expenditure, such as fiscal instruments, affects on the GDP per capita, unemployment rate and human development index.

\section{Materials and methods}

Secondary data were used as data sources from: Trading Economics, Eurostat, The World Bank, UNCTADstat, The Global Economy, IMF and United Nations. As a macro analysis unit eight Southeast European countries were selected without Montenegro because of the inaccessibility of most data.

The task of the empirical research was to determine the relationship of fiscal policy instruments with two groups of dependent variables. In order to test individual hypotheses, an empirical research as a basis had a positivistic scientific paradigm which chosen because of its inherent insistence on isolating only some of the relevant indicators for analysis and insisting on a more precise measurement of the relationship between them (Lancaster, 2005, Wilson, 2010). Such a paradigm in view of the goals 
set in this paper corresponded to the quantitative methodology because the essence was an attempt to describe and explain the behavior in the field of finance by collecting a large number of individual data of an objective nature and numerical character, and according to a prestructured conceptual framework (Lee, Lee, Lee, 2010). The selected analysis techniques were conditioned by the numerical nature of the independent and dependent variables, that is, the fact that all the analyzed variables are time series.

The first level of analysis was the construction of Autoregressive Integrated Moving Average Model, ARIMA. The goal of constructing this model through an expert option in the SPSS computer program was to describe and evaluate the relationship between the variables analyzed (Yaffee, McGee 2000, Brockwell, Davis 2002, Montgomery, Jennings, Kulahci, 2008). ARIMA models are among the most efficient linear models for analyzing time series in macroeconomics and finance due to their flexibility (Montgomery, Jennings, Kulahci, 2008). Since the precondition of Box- Jenkins methodology, which is the essence of the ARIMA model, is the completeness of the time series it is operating with the first step in building the ARIMA model was to replace the data missing from the corresponding algorithms (Yaffee, McGee, 2000). In accordance with the recommended methods for removing this defect in time series that were not too asymmetrical, the missing data in them were replaced by the arithmetic mean of the string, while in the cases of time series that had a high degree of asymmetry of missing data replicated using mediation (Armstrong, 2006). The ARIMA model procedure can be represented by the following formula (Weisang, Awazu, 2008):

$$
\varphi_{p}(B)\left[\Delta\left(Y_{t}-\sum_{i * 1}^{m} C_{i} X_{i t}\right)-\mu\right]=\Theta_{q}(B) a_{t}
$$

where is:

$$
\begin{aligned}
& B=\text { the backshift operator, } \mathrm{BX}_{\mathrm{t}}=\mathrm{X}_{\mathrm{t}}-1 \\
& \Delta=\text { the differencing operator, } \Delta=(1-\mathrm{B})^{\mathrm{d}} \\
& \varphi_{p}(B)=\text { the AR polynomial, } \\
& \Theta_{q}(B)=\text { the MA polynomial }(\mathrm{MA}) \\
& X_{i t}=\text { independent variable } \\
& Y_{t}=\text { dependent variable. }
\end{aligned}
$$

The second level of analysis was to determine the existence of statistically significant differences between the macro analysis units. Friedman's test is used to estimate the difference between three and more types of data derived from successive measurements, and is an alternative to the analysis of variance in cases where this test can not be applied due to a violation of its assumptions (Gravetter, Wallnau, 2017). The essence of this test is the chi-square, $\chi 2$, statistics that rank the sums of squares for each column of data and their entrances involved in testing (Dalgaard, 2008). 


\section{Results}

The results of the ARIMA model were presented as a test results for the individual hypotheses by each country. Based on the observed Stationary R-squared concluded that in all countries models were suitable for analyzing given data.

In the case of Albania (Table A1) the obtained data didn't give arguments to confirm H1 hypothesis, but confirmed $\mathrm{H} 2$ in the case of GDP per capita and human development index as a economic development indicators. In FYR of Macedonia (Table A2) H1 was confirmed in the case of a budget deficit/surplus and H2 for GDP per capita and human development index. In B\&H (Table A3) H1 was confirmed for budget deficit/surplus, and confirmed the $\mathrm{H} 2$ in the case of GDP per capita and human development index. In Bulgaria (Table A4) H1 was confirmed in the case of public debt and budget deficit/ surplus, and $\mathrm{H} 2$ in the case of the unemployment rate and the human development index. In Greece (Table A5) the obtained data gave an argument for the confirmation hypothesis $\mathrm{H} 1$ and the H2. In Romania (Table A6) H1 was confirmed in the case of a budget deficit/surplus and $\mathrm{H} 2$ in the case of GDP per capita, unemployment rate and human development index. In Serbia (Table A7) H1 hypothesis was confirmed in the case of public debt, and the hypothesis $\mathrm{H} 2$ confirmed in the case of GDP per capita and human development index. In Croatia (Table A8) H1 hypothesis was confirmed in the case of a budget deficit/surplus, and confirmed H2 in the case of GDP per capita and human development index as a economic development indicators.

Table 1. Results of Friedman's test

\begin{tabular}{|c|c|c|c|c|c|c|}
\hline \multicolumn{7}{|c|}{ Test Statistics ${ }^{\mathrm{a}}$} \\
\hline & & p_debit & suf_def & gdp_pc & Unemplo & hd_index \\
\hline \multicolumn{2}{|l|}{$\mathrm{N}$} & 8 & 8 & 8 & 8 & 8 \\
\hline \multicolumn{2}{|l|}{ Chi-square } & 64.025 & 55.355 & 89.581 & 27.337 & 123.142 \\
\hline \multicolumn{2}{|l|}{ Df } & 16 & 16 & 16 & 16 & 16 \\
\hline \multicolumn{2}{|l|}{ Asymp. Sig. } & $.000 * * *$ & $.000 * * *$ & .000 *** & $.038^{*}$ & $.000 * * *$ \\
\hline \multirow{17}{*}{ Mean Rank } & 2000 & 11.94 & 9.44 & 11.75 & 9.19 & 1.19 \\
\hline & 2001 & 11.13 & 8.63 & 10.00 & 10.00 & 2.00 \\
\hline & 2002 & 10.94 & 8.19 & 11.38 & 9.88 & 2.88 \\
\hline & 2003 & 8.63 & 9.63 & 11.38 & 8.25 & 3,94 \\
\hline & 2004 & 7.38 & 12.31 & 14.19 & 10.25 & 5.00 \\
\hline & 2005 & 7.50 & 13.31 & 12.00 & 8.94 & 6.00 \\
\hline & 2006 & 4.75 & 13.50 & 14.31 & 9.19 & 7.13 \\
\hline & 2007 & 2.75 & 12.81 & 14.88 & 6.50 & 7.94 \\
\hline & 2008 & 3.13 & 8.81 & 12.88 & 3.00 & 9.44 \\
\hline & 2009 & 6.13 & 2.88 & 2.50 & 5.69 & 10.56 \\
\hline & 2010 & 7.25 & 5.25 & 4.38 & 9.50 & 11.56 \\
\hline & 2011 & 8.50 & 5.50 & 4.94 & 11.13 & 12.00 \\
\hline & 2012 & 9.88 & 6.69 & 2.38 & 10.75 & 12.50 \\
\hline & 2013 & 11.44 & 5.69 & 5.40 & 12.63 & 14.13 \\
\hline & 2014 & 14.13 & 6.25 & 5.75 & 11.38 & 15.31 \\
\hline & 2015 & 13.94 & 10.75 & 7.50 & 9.50 & 16.63 \\
\hline & 2016 & 13.63 & 13.38 & 7.61 & 7.25 & 16.81 \\
\hline
\end{tabular}

Source: Author's calculation, Notes: ${ }^{*} \mathrm{p}<0.05 ; * * \mathrm{p}<0.01 ; * * * \mathrm{p}<0.001$ 
The results of the Friedman test showed that the existence of a statistically significant difference in: the public debt of the analyzed countries for a period of 16 years at the level of $\chi 2(16.8)=64.025, \mathrm{p}=.000$, with a declining ranking of the arithmetic mean in the period from 2000 to 2008, growth the ranking of the arithmetic mean between 2008 and 2014, and its mild fall in 2015 and 2016; in the budget surplus/deficit $\chi^{2}$ (16.8) $=55.355, \mathrm{p}=.000$, with decreasing arithmetic mean in the period from 2000 to 2003, growth the ranking of the arithmetic mean from 2003 to 2006, a fall it in the period from 2006 to 2009, and its fluctuations in the period from 2009 to 2016; in GDP per capita $\chi^{2}(16.8)=89.581, \mathrm{p}=.000$, with frequent fluctuations in the arithmetic mean ranges from 2000 to 2012, but with an huge fall in 2009, and a rise it from 2012 to 2016 ; in the unemployment rate $\chi 2(16.8)=27.337, p=.038$, with the fluctuations of the arithmetic mean ranking from 2000 to 2008, growth it from 2008 to 2011, refluctuation in the period from 2011 to 2013, and its decline in the period from 2014 to 2016 and in the human development index $\chi^{2}(16.8)=123.142, p=.000$, with careless growth of the arithmetic mean in the observed period.

\section{Discussions}

Fiscal policy instruments records different results because we have abstracted reality from other influences. The most represented influence of fiscal policy instruments is on the human development index as a comprehensive measure of economic development which expressed in all observed countries, with the biggest significant in Greece, $\mathrm{p}<0.000$, where is the best results of the study that both hypotheses were fully proven, Serbia, $p<0.000$ and Croatia $p<0.001$, as well as on the GDP per capita, where only Bulgaria has not recorded this connection with it. Regarding the impact on macroeconomic fiscal indicators, the most significant is the impact on the budget surplus/deficit, where only Serbia and Albania have not been recorded.

Friedman test showed that economic crisis turned into a crisis of public debts (Reinhart, Rogoff, 2011), as well as that it had an impact on the decline in economic activity and the rise in unemployment. The economic crisis turned into a crisis of public debts and most affected the public debt of the countries, as they fell to 2008, and since then, they have grown, with a slight tendency of decreasing the arithmetic mean in 2015 and 2016. There are frequent fluctuations in budget deficits/surpluses. GDP per capita in 2009 recorded a major drop and has not yet returned to the precrisis level, although there is a tendency for growth after 2012. The crisis has also had an impact on unemployment, which had a tendency to decline by 2008, since it is growing. It is good that this growth was stopped in 2014. The human development index was been recording steady fluctuations.

Observing public expenditures and revenue from taxes in absolute values, the management of an expansive or restrictive policy has been established. From the point of view of the public expenditures of the observed countries, they led an expansive fiscal policy by 2008 until they increase. It is noticeable that all countries in 2016 have less public expenditures compared to 2009 so it can be said that the crisis has imposed 
a restrictive fiscal policy. What is worrying is that states continue to reduce public expanditures, which means they have not yet recovered from the crisis. Income from taxes is until 2008 grew up. The reason for this growth can be used for further research to see if the countries concerned with this item have led a restrictive policy and are incompatible with public expenditures or the reason for better tax collection was the expansion of the tax base, or some other indicators relating to efficiency. In 2009 they are falling in all countries, but in B\&H since 2010 they are in the rise, in Croatia since 2012, Macedonia in 2010, Bulgaria in 2011, Romania and Serbia in 2010 (with slight fluctuations in all countries), which can give indications of a restrictive fiscal policy. Unlike these countries, they continue to decline in Greece, also with slight fluctuations. This can give an answer to the notion that more developed countries can implement a countercyclical fiscal policy, unlike developing countries that carry out a procyclical fiscal policy. Also, this gives a signal to agricultural households in those countries, and when it comes to Serbia from the implementation of fiscal policy also depend whether it would enter the VAT system, from which they can benefit, considering that agricultural production in our conditions has great importance and series of specifics in relation to other activities, and on the other hand, it's a tax that represents the most important source of tax revenues in the budget of the Republic of Serbia (Tica et al., 2011). Also, the entry into the VAT system is especially justified for agricultural households that have significant investments in agricultural production (Tica et al., 2011). Adequate fiscal and agricultural policies are needed for the poor who live mainly in rural areas and are employed mainly in agriculture which is the dominant economic activity (Zekić et al., 2016), both globally (World bank group, 2016) and in Serbia (Maksimović, 2011). Also, agricultural production is a very specific area of the entire economy of the Republic of Serbia, provides the basic source of income for all persons engaged in agricultural production activities and has great economic and social significance (Zelenović, Vojinović, Cvijanović, 2018).

\section{Conclusions}

Observed countries have not yet recovered from the effects of the crisis and were forced to led restrictive fiscal policies so that the consequences would not be even worse, which also reflected on economic development and agricultural policy.

Recommendations for further research should be establish link between the economic cycle (expansion, recession) and economic policy implementation (expansive, restrictive), look at the profile and causes of poverty rural areas and farmers and set up an appropriate fiscal policy, especially in the context of allocation for education, health care, social benefits and inclusion, and also compare these indicators with some reference values of developed countries.

Some limitations are that economists with a high degree of openness can be deenergized to use fiscal stimulus, because, as the economy is more open, fiscal stimulus less benefits the domestic economy (Praščević, 2012). Unlike the authors who dealing with fiscal policy constraints (time lag, tax multipliers, Laffer and Armey-Rahn curves, etc.) 
is a tearful number of those who deal with social welfare, especially empirical research and the reflection on the lives of individuals. There is no measure that can cover all the complexity of what is happening in modern society. An expansive fiscal policy can increase budget deficits and public debt, while a restrictive one can lead to social exclusion, for which farmers are exposed in the most cases.

What is positive and what can be derived as a general conclusion is that fiscal policy instruments can influence development indicators and that restrictive fiscal policy in the observed countries has yielded results, ie improvements in the recent years have been recorded in all observed dependent variables. Also, instruments of fiscal policies in all countries have had an impact on the human development index as a comprehensive measure of economic development.

This has just proven the general hypothesis that fiscal policy instruments can affect indicators of economic development, but these indicators are generally far from precrisis level, which means that the basis for the implementation of expansive fiscal policy and the growth of social welfare has not yet been created. Therefore, states have to conduct responsible fiscal policy in accordance with their capabilities in order to reduce poverty and social inequalities, which is particularly pronounced in rural areas where agriculture is the dominant economic activity. Economic policy should not be limited only to responsible implementation of fiscal policy, than to all the elements that should lead to sustainable development. It should involve all social groups which will reduce inequality and create conditions for economic development.

\section{Acknowledgements}

This work was supported by the Ministry of Science, Education and Technological development of the Republic of Serbia under Grant number III47005.

\section{Conflict of interests}

The authors declare no conflict of interest.

\section{References}

1. Acemoglu, D. (2006). Introduction to economic growth. The MIT Press, London.

2. Aghion, P., \& Howitt, P. (2009). The economics of growth. The MIT Press, London.

3. Allen, F., Carletti, E., Goldstein, I., \& Leonello, A. (2015). Moral Hazard and Government Guarantees in the Banking Industry. Journal of Financial Regulation, 1(1), 30-50. doi: https://doi.org/10.1093/jfr/fju003.

4. Aničić, D., Nestorović, O., Simić, N., \& Miletić, S. (2019). The Perspectives of Sustainable Development of Serbia's Agriculture in Globalized Environment. Economics of Agriculture. 66(1), 221-235. https://doi.org/10.5937/ ekoPolj1901221A. 
5. Armstrong, J.S. (2006). Findings from evidence-based forecasting: Methods for reducing forecast error. International Journal of Forecasting, 22(3), 583-598. doi: https://doi.org/10.1016/j.ijforecast.2006.04.006.

6. Balatsky, E., \& Ekimova, H. (2012). Fiscal Policy and Economic Growth. Problems of Economic Transition, 54(12), 55-70. doi: 10.2753/PET1061-1991541204.

7. Bleaney, M., Gemmel, N., \& Kneller, R. (2001). Testing the endogenous growth model: public expenditure, taxation, and growth over the long run. Canadian Journal of Economics, 34(1), 36-57. doi: 10.1111/0008-4085.00061.

8. Brockwell, P.J., \& Davis, R.A. (2002). Introduction to Time Series and Forecasting, $2^{\text {nd }}$ ed. Springer-Verlag New York Inc, New York.

9. Bryne, D., \& Ruane, S. (2017). Paying For The Welfare State In The 21st Century: Tax And Spending In Post-industrial Societies. Bristol University Press, Bristol.

10. Caprio, G., D’Apice, V., Ferri, G., \& Walter Puopolo G. (2014). Macro-financial determinants of the great financial crisis: Implications for financial regulation. Journal of Banking \& Finance, 44(7), 114-129. https://doi.org/10.1016/j.jbankfin.2014.03.001.

11. Claessens, S., Ayhan Kose M., Laeven, L., \& Valencia F. (2014). Financial Crises: Causes, Consequences and Policy Responses. International Monetary Fund, Washington, D. C.

12. Corporate Profit Taxual Law according to "Official Gazette RS “, no. 95/2018 [In Serbian: Zakon o porezu na dobit pravnih lica "Sl. Glasnik RS”, br. 95/2018].

13. Dalgaard, P. (2008). Introductory Statistics with R, 2nd ed. Springer, New York, NY.

14. Despotović D. (2015). The importance of fiscal consolidation in the process of EU accession. In: M. Jakšić, V. Stojanović Aleksić, P. Mimović (Eds.), Economic and social aspects of Serbia's accession to the European Union (pp. 127-140). Faculty of Economics, University of Kragujevac, Kragujevac. [In Serbian: Despotović D. (2015). Značaj fiskalne konsolidacije u procesu pristupanja EU. U: M. Jakšić, V. Stojanović Aleksić, P. Mimović (Eds.), Ekonomsko-socijalni aspekti priključivanja Srbije Evropskoj uniji].

15. Despotović, D., \& Durkalić, D. (2017), Analysis of budget deficit in the candidate countries for EU membership, Serbian Journal of Management, 12 (2), 237-253. DOI: $10.5937 /$ sjm12-14122.

16. Domanović, V., Vujičić, M, \& Ristić, L. (2018). Profitability of Food Industry Companies in The Republic of Serbia. Economics of Agriculture. 65(1), 11-32. doi:10.5937/ekoPolj1801011D.

17. Fabris, N., \& Pejović, I. (2013). Economic Policy - Theory and Practice. High School of Economics and Administration, Belgrade. [In Serbian: Fabris, N., Pejović, I. (2013). Ekonomska politika-teorija i praksa].

18. Furtula, S., Durkalić, D., \& Simionescu, M. (2018). Testing Phillips Curve For Serbian And Romanian Economy. Romanian Statistical Review, (3), 40-56. http:// www.revistadestatistica.ro/wp-content/uploads/2018/09/RRS-3_2018_A4.pdf. 
19. Gravetter, F.J., \& Wallnau, L.B. (2017). Statistics for the Behavioral Sciences. $10^{\text {th }}$ ed. Cengage Learning, Boston, MA.

20. Hyers, D., \& Kovacova, M. (2018). The Economics of the Online Gig Economy: Algorithmic Hiring Practices, Digital Labor-Market Intermediation, and Rights for Platform Workers. Psychosociological Issues in Human Resource Management, 6(1), 160-165.

21. Hamilton, K., \& Hepburn, C. (2017). National Wealth: What Is Missing, Why It Matters. Oxford University Press, Oxford.

22. Kovačević, R. (2010). International finances. Center for publishing at the Faculty of Economics in Belgrade, Belgrade. [In Serbian: Kovačević, R. (2010). Međunarodne finansije].

23. Koppel, J., \& Kolencik, J. (2018). The Future of Workers: Contingent Forms of Labor Contracting in the Platform Economy. Psychosociological Issues in Human Resource Management, 6(1), 172-177

24. Lancaster, G. (2005). Research Methods in Management: A Concise Introduction to Research in Management and Business Consultancy. Butterworth-Heinemann, Oxford.

25. Lazonick, W. (2014). Profit without Prosperity: Stock Buybacks Manipulate The Market And Leave Most Americans Worse Off. Harward Business Review, September, 46-55. Retrieved from https://hbr.org/2014/09/profits-withoutprosperity.

26. Lee, C.,F., Lee, A.C., \& Lee, J. (2010). Handbook of Quantitative Finance and Risk Management. Springer, New York, NY.

27. Maksimović, G. (2011). Demographic factors of local economic development in the Republic of Serbia, Agroeconomics, 49-50(2011). 47-57. [In Serbian: Maksimović, G. (2011). Demografski faktori lokalnog ekonomskog razvoja u Republici Srbiji. Agroekonomika].

28. Montgomery, D.C., Jennings, C.L., \& Kulahci, M. (2008). Introduction to Time Series - Analysis and Forecasting. John Wiley \& Sons Inc, Hoboken, NJ.

29. Moreno-Dodson, B. (2013). Is fiscal policy the answer?. The world bank, Washington.

30. Popescu, G. H., Petrescu, I. E., \& Sabie, O. M. (2018). Algorithmic labor in the platform economy: digital infrastructures, job quality, and workplace surveillance. Economics, Management and Financial Markets, 13(3), 74-79.

31. Praščević, A. (2012). Economic Crises and Macroeconomic Policy Models. Center for publishing at the Faculty of Economics in Belgrade, Belgrade. [In Serbian: Praščević, A. (2012). Ekonomske krize i modeli makroekonomske politike].

32. Reinhart, C. M., \& Rogoff, K. S. (2011). From Financial Crash to Debt Crisis. American Economic Review, 101(5), 1676-1706. doi:10.1257/aer.101.5.1676

33. Ristić, L. (2015). Economics of agriculture. Faculty of Economics, University of 
Kragujevac, Kragujevac [In Serbian: Ristić, L. (2015). Ekonomika poljoprivrede].

34. Rozen, H., \& Gejer, T. (2009). Public finances. Center for publishing at the Faculty of Economics in Belgrade, Belgrad. [In Serbian: Rozen, H., Gejer, T. (2009). Javne finansije].

35. Singh, S. K., \& Rao, D. T. (2018). Is Monetary Policy Symmetrical in Its Effect on Sectoral Output?. Economics, Management, and Financial Markets, 13(1), 11-31. doi:10.22381/EMFM13120181.

36. Stanković, K. (2006). Modern economic theories, principles and politics. Faculty of Economics, University of Kragujevac, Kragujevac. [In Serbian: Stanković, K. (2006). Savremene ekonomske teorije, principi i politika].

37. Sekera, J. (2018). Missing from the mainstream: the biophysical basis of production and the public economy. Economics, Management, and Financial Markets, 13(3), 56-73.

38. Stiglic, J.E. (2013). Free fall. Academic book, Novi Sad. [In Serbian: Stiglic, J.E. (2013). Slobodan pad].

39. Taylor, L., \& Kliestikova, J. (2018). The Operational Coherence of the Workforceas-a-service Pattern: Digitally Mediated Service Work, the Contingency of Ondemand Employment, and the Low-income Labor Market. Psychosociological Issues in Human Resource Management, 6(1), 178-183.

40. Tica, N., Zekić, V., Milić, D., \& Đajić, D. (2011). Agricultural households in the system of value added tax. Agroeconomics, 51-52(2011), 32-39 [In Serbian: Tica, N., Zekić, V., Milić, D., Đajić, D. (2011). Poljoprivredna gazdinstva u sistemu popreza na dodatu vrednost. Agroekonomika].

41. Thiele, A. (2018). The independence of the ECB: justification, limitations and possible threats. Journal of Self-Governance and Management Economics, 6(1), 98-121.

42. Todaro, M.P., \& Smith, S.C. (2006). Economic development. Tajib Šahinpašić, Sarajevo. [In Serbian: Todaro, M.P., Smith, S.C. (2006). Ekonomski razvoj].

43. Value Added Taxual Law according to "Official Gazette RS “, no. 30/2018 [In Serbian: Zakon o porezu na dodatu vrednost prema "Sl. Glasnik RS”, br. 30/2018].

44. Vujičić, M., \& Ristić, L. (2006). Economics of agriculture. Interprint, Kragujevac. [In Serbian: Vujičić, M., Ristić, L. (2006). Ekonomika poljoprivrede].

45. Vukadin, E., \& Labus, M. (2012). Economic Policy for Lawyers. Faculty of Law, University of Belgrade, Belgrade. [In Serbian: Vukadin, E., Labus, M. (2012). Ekonomska politika za pravnike].

46. Weisang, G., \& Awazu, Y. (2008). Vagaries of the Euro: An Introduction to ARIMA Modeling. The Bentley University Journal, 2(1), 45-55. Retrieved from https:// www.bentley.edu/sites/www.bentley.edu.centers/files/csbigs/weisang.pdf.

47. Wilson, J. (2010). Essentials of Business Research: A Guide to Doing Your Research Project. SAGE Publications, London. 
48. World bank group. (2016). Taking on inequality - Poverty and shared prosperity 2016, The World bank, Washington.

49. Yaffee, R.A., \& McGee, M. (2000). Introduction to Time Series Analysis and Forecasting with Applications of SAS and SPSS. Academic Press Inc, San Diego.

50. Yifu Lin J. (2012). New structural economics: a framework for rethinking development and policy. The world bank, Washington.

51. Zekić, S., Matkovski, B., \& Kleut, Ž. (2016). IPARD funds in the function of development of rural areas of the Republic of Serbia, Economic horizons, 18(2), 169-180. [In Serbian: Zekić, S., Matkovski, B., Kleut, Ž. (2016). IPARD fondovi u funkciji razvoja ruralnih područja Republike Srbije, Ekonomski horizonti]. doi:10.5937/ekonhor1602169Z.

52. Zelenović, V., Vojinović, Ž., \& Cvijanović, D. (2018). Serbian Agriculture Loans With The Aim of Improving The Current Situation. Economics of Agriculture. 65(1), 323-336. doi:10.5937/ekoPolj1801323Z.

\section{Appendices}

Table A1. ARIMA model in the case of Albania

\begin{tabular}{|c|c|c|c|c|c|}
\hline \multicolumn{3}{|l|}{ Model Fit } & \multicolumn{3}{|l|}{ Model Statistics } \\
\hline Fit Statistic & Mean & SE & Model & $\begin{array}{l}\text { Number of } \\
\text { Predictors }\end{array}$ & \begin{tabular}{|l|} 
Stationary \\
R-squared
\end{tabular} \\
\hline $\begin{array}{l}\text { S tation ary } \\
\text { R-squared }\end{array}$ & \begin{tabular}{l|l}
$\mathrm{y}$ & .364 \\
\end{tabular} & .148 & p_debit-Model_1 & 2 & .098 \\
\hline R-squared & .364 & .148 & suf_def-Model_2 & 2 & .073 \\
\hline RMSE & 2.466 & 2.235 & gdp_pc-Model_3 & 2 & .364 \\
\hline MAE & 1.853 & 1.777 & unemplo-Model_4 & 2 & .043 \\
\hline $\begin{array}{l}\text { Normalized } \\
\text { BIC }\end{array}$ & \begin{tabular}{l|l}
$\mathrm{d}$ & .709
\end{tabular} & 4.060 & hd_index-Model_5 & 2 & .308 \\
\hline \multicolumn{6}{|c|}{\begin{tabular}{|l} 
ARIMA Model Parameters \\
\end{tabular}} \\
\hline Model & Estimate & & SE & $\mathrm{T}$ & Sig. \\
\hline $\begin{array}{l}\mathrm{p} \text {-d e bit }- \\
\text { Model_1 }\end{array}$ & -9.051 & & 57.830 & -.157 & .878 \\
\hline $\begin{array}{l}\text { suf_d e f- } \\
\text { Model_2 }\end{array}$ & -20.408 & & 15.345 & -1.330 & .205 \\
\hline $\begin{array}{l}\mathrm{g} \mathrm{d} \mathrm{p}_{\text {Mod__ }} \mathrm{pc}- \\
\text { Model }\end{array}$ & 41.473 & & .673 & 2.108 & $.041^{*}$ \\
\hline $\begin{array}{l}\text { unemplo- } \\
\text { Model_4 }\end{array}$ & -3.721 & & 23.756 & -.157 & .878 \\
\hline \begin{tabular}{l|} 
hd_index- \\
Model_5
\end{tabular} & 36.029 & & .312 & .926 & $.049 *$ \\
\hline
\end{tabular}

Source: Author's calculation, Notes: $* \mathrm{p}<0.05 ; * * \mathrm{p}<0.01 ; * * * \mathrm{p}<0.001$ 
Table A2. ARIMA model in the case of FYR of Macedonia

\begin{tabular}{|l|l|l|l|l|l|}
\hline Model Fit & Mean & SE & Model & $\begin{array}{l}\text { Number of } \\
\text { Predictors }\end{array}$ & $\begin{array}{l}\text { Stationay R R } \\
\text { squared }\end{array}$ \\
\hline Stationary R-squared & .373 & .294 & p_debit-Model_1 & 2 & .068 \\
\hline R-squared & .373 & .294 & suf_def-Model_2 & 2 & .543 \\
\hline RMSE & 3.562 & 4.530 & gdp_pc-Model_3 & 2 & .778 \\
\hline MAE & 2.626 & 3.459 & unemplo-Model_4 & 2 & .131 \\
\hline Normalized BIC & .748 & 4.714 & hd_index-Model_5 & 2 & .344 \\
\hline ARIMA Model Parameters & Estimate & SE & T & Sig. \\
\hline Model & -9.191 & 92.722 & -.099 & .922 \\
\hline p_debit-Model_1 & -.755 & .226 & -3.344 & $.005 * *$ \\
\hline suf_def-Model_2 & -.833 & .165 & -5.050 & $.000^{* * *}$ \\
\hline gdp_pc-Model_3 & 2.048 & 1.428 & 1.435 & .173 \\
\hline unemplo-Model_4 & -.007 & .003 & -2.236 & $.042^{*}$ \\
\hline hd_index-Model_5 & &
\end{tabular}

Source: Author's calculation, Notes: ${ }^{*} \mathrm{p}<0.05 ; * * \mathrm{p}<0.01 ; * * * \mathrm{p}<0.001$

Table A3. ARIMA model in the case of Bosnia and Herzegovina

\begin{tabular}{|l|l|l|l|l|l|}
\hline Model Fit & Mean & SE & Model & $\begin{array}{l}\text { Number of } \\
\text { Predictors }\end{array}$ & $\begin{array}{l}\text { S Stationary } \\
\text { R- R-squared }\end{array}$ \\
\hline Fit Statistic & .287 & .143 & p_debit-Model_1 & 2 & .163 \\
\hline Stationary R-squared & .287 & .143 & suf_def-Model_2 & 2 & .485 \\
\hline R-squared & 2.358 & 1.998 & gdp_pc-Model_3 & 2 & .368 \\
\hline RMSE & 1.734 & 1.414 & unemplo-Model_4 & 2 & .144 \\
\hline MAE & .597 & 4.176 & hd_index-Model_5 & 2 & .274 \\
\hline Normalized BIC & & & SE & T & Sig. \\
\hline ARIMA Model Parameters & Estimate & 1.456 & 1.153 & .268 \\
\hline Model & 1.679 & .655 & 2.341 & $.035^{*}$ \\
\hline p_debit-Model_1 & 1.533 & .953 & 2.227 & $.043 *$ \\
\hline suf_def-Model_2 & 2.122 & 1.257 & 1.270 & .225 \\
\hline gdp_pc-Model_3 & 1.596 & .359 & 3.484 & $.048^{*}$ \\
\hline unemplo-Model_4 & 1.251 & & \\
\hline hd_index-Model_5 & & & & \\
\hline
\end{tabular}

Source: Author's calculation, Notes: ${ }^{*} \mathrm{p}<0.05 ; * * \mathrm{p}<0.01 ; * * * \mathrm{p}<0.001$ 
Table A4. ARIMA model in the case of Bulgaria

\begin{tabular}{|c|c|c|c|c|c|}
\hline \multicolumn{3}{|l|}{ Model Fit } & \multicolumn{3}{|l|}{ Model Statistics } \\
\hline Fit Statistic & Mean & SE & Model & \begin{tabular}{|l|} 
Number of \\
Predictors
\end{tabular} & \begin{tabular}{|l|} 
Stationary \\
R-squared
\end{tabular} \\
\hline Stationary R-squared & $\mathrm{d} .324$ & .227 & p_debit-Model_1 & 2 & .511 \\
\hline R-squared & .324 & .227 & suf_def-Model_2 & 2 & .224 \\
\hline RMSE & 4.296 & 5.308 & gdp_pc-Model_3 & 2 & .092 \\
\hline MAE & 3.256 & 4.107 & unemplo-Model_4 & 2 & .615 \\
\hline Normalized BIC & 1.305 & 4.541 & hd_index-Model_5 & 2 & .177 \\
\hline \multicolumn{6}{|c|}{ ARIMA Model Parameters } \\
\hline Model & Estimate & & SE & $\mathrm{T}$ & Sig. \\
\hline p_debit-Model_1 & 3.414 & & 1.357 & 2.515 & $.025^{*}$ \\
\hline suf_def-Model_2 & 1.383 & & .277 & 1.382 & $.047^{*}$ \\
\hline gdp_pc-Model_3 & .084 & & .331 & .254 & .803 \\
\hline unemplo-Model_4 & -1.506 & & .366 & -4.115 & $.001 * * *$ \\
\hline hd_index-Model_5 & 1.005 & & .004 & 1.008 & $.049 *$ \\
\hline
\end{tabular}

Source: Author's calculation, Notes: ${ }^{*} \mathrm{p}<0.05 ; * * \mathrm{p}<0.01 ; * * * \mathrm{p}<0.001$

Table A5. ARIMA model in the case of Greece

\begin{tabular}{|l|l|l|l|l|l|}
\hline Model Fit & Mean & SE & Model & $\begin{array}{l}\text { Number of } \\
\text { Predictors }\end{array}$ & $\begin{array}{l}\text { Stationay R } \\
\text { squared }\end{array}$ \\
\hline Stationary R-squared & .624 & .172 & p_debit-Model_1 & 2 & .698 \\
\hline R-squared & .624 & .172 & suf_def-Model_2 & 2 & .707 \\
\hline RMSE & 5.701 & 7.886 & gdp_pc-Model_3 & 2 & .572 \\
\hline MAE & 3.839 & 5.499 & unemplo-Model_4 & 2 & .793 \\
\hline Normalized BIC & 1.345 & 5.291 & hd_index-Model_5 & 2 & .352 \\
\hline ARIMA Model Parameters & & & & \\
\hline Model & Estimate & 73.614 & -3.627 & $.003 * *$ \\
\hline p_debit-Model_1 & -266.974 & 8.222 & 2.549 & $.023 *$ \\
\hline suf_def-Model_2 & -7.839 & 11.744 & -3.886 & $.002^{* *}$ \\
\hline gdp_pc-Model_3 & 29.932 & 13.448 & -6.176 & $.000^{* * *}$ \\
\hline unemplo-Model_4 & -83.054 & .065 & 11.587 & $.000^{* * *}$ \\
\hline hd_index-Model_5 & .750 & &
\end{tabular}

Source: Author's calculation, Notes: ${ }^{*} \mathrm{p}<0.05 ; * * \mathrm{p}<0.01 ; * * * \mathrm{p}<0.001$ 
Table A6. ARIMA model in the case of Romania

\begin{tabular}{|l|l|l|l|l|l|}
\hline Model Fit & Mean & SE & Model & $\begin{array}{l}\text { Number of } \\
\text { Predictors }\end{array}$ & $\begin{array}{l}\text { Stationary } \\
\text { R-squared }\end{array}$ \\
\hline Stationary R-squared & .367 & .363 & p_debit-Model_1 & 2 & .000 \\
\hline R-squared & .367 & .363 & suf_def-Model_2 & 2 & .954 \\
\hline RMSE & 2.930 & 4.397 & gdp_pc-Model_3 & 2 & .493 \\
\hline MAE & 2.270 & 3.556 & unemplo-Model_4 & 2 & .239 \\
\hline Normalized BIC & .002 & 4.352 & hd_index-Model_5 & 2 & .202 \\
\hline ARIMA Model Parameters & Estimate & & SE & T & Sig. \\
\hline Model & .189 & 2.734 & .069 & .946 \\
\hline p_debit-Model_1 & .957 & .144 & 6.653 & $.000^{* * *}$ \\
\hline suf_def-Model_2 & .957 & -319 & 4.420 & $.015^{*}$ \\
\hline gdp_pc-Model_3 & -.888 & 2.902 & 2.056 & $.041^{*}$ \\
\hline unemplo-Model_4 & 12.826 & .200 & .788 \\
\hline hd_index-Model_5 & .410 &
\end{tabular}

Source: Author's calculation, Notes: $* \mathrm{p}<0.05$; $* * \mathrm{p}<0.01 ; * * * \mathrm{p}<0.001$

Table A7. ARIMA model in the case of Serbia

\begin{tabular}{|c|c|c|c|c|c|}
\hline \multicolumn{3}{|l|}{ Model Fit } & \multicolumn{3}{|l|}{ Model Statistics } \\
\hline Fit Statistic & Mean & SE & Model & $\begin{array}{l}\text { Number of } \\
\text { Predictors }\end{array}$ & $\begin{array}{l}\text { Stationary } \\
\text { R-squared }\end{array}$ \\
\hline Stationary R-squared & .471 & .252 & p_debit-Model_1 & 2 & .595 \\
\hline R-squared & .471 & .252 & suf_def-Model_2 & 2 & .144 \\
\hline RMSE & 6.982 & 11.387 & gdp_pc-Model_3 & 2 & .395 \\
\hline MAE & 4.893 & 7.868 & unemplo-Model 4 & 2 & .183 \\
\hline Normalized BIC & 1.123 & 5.785 & hd_index-Model_5 & 2 & .820 \\
\hline \multicolumn{6}{|c|}{ ARIMA Model Parameters } \\
\hline Model & Estimate & & SE & $\mathrm{T}$ & Sig. \\
\hline p_debit-Model_1 & -9.705 & & 2.161 & -4.491 & $.001 * * *$ \\
\hline suf_def-Model_2 & -3.647 & & 7.262 & -1.879 & .081 \\
\hline gdp_pc-Model_3 & 1.217 & & .431 & 2.822 & $.014 *$ \\
\hline unemplo-Model_4 & 4.314 & & 1.730 & -1.460 & .203 \\
\hline hd_index-Model_5 & .887 & & .040 & 22.173 & $.000 * * *$ \\
\hline
\end{tabular}

Source: Author's calculation, Notes: ${ }^{*} \mathrm{p}<0.05 ; * * \mathrm{p}<0.01 ; * * * \mathrm{p}<0.001$ 
Table A8. ARIMA model in the case of Croatia

\begin{tabular}{|l|l|l|l|l|l|}
\hline Model Fit & Mean & SE & Model & $\begin{array}{l}\text { Number of } \\
\text { Predictors }\end{array}$ & $\begin{array}{l}\text { Stationary } \\
\text { R-squared }\end{array}$ \\
\hline Stationary R-squared & .294 & .150 & p_debit-Model_1 & 2 & .087 \\
\hline R-squared & .294 & .150 & suf_def-Model_2 & 2 & .381 \\
\hline RMSE & 5.074 & 7.450 & gdp_pc-Model_3 & 2 & .431 \\
\hline MAE & 3.939 & 6.034 & unemplo-Model_4 & 2 & .143 \\
\hline Normalized BIC & 1.248 & 4.701 & hd_index-Model_5 & 2 & .326 \\
\hline ARIMA Model Parameters & Estimate & SE & 7.000 & T & .156 \\
\hline Model & -1.398 & 3.521 & -2.693 & Sig. \\
\hline p_debit-Model_1 & 2.539 & -2.608 & .878 \\
\hline suf_def-Model_2 & -6.417 & 1.107 & -.126 & $.017 *$ \\
\hline gdp_pc-Model_3 & -9.223 & .294 & 4.068 & .902 \\
\hline unemplo-Model_4 & 1.778 & 1.197 & & & $.001 * * *$ \\
\hline hd_index-Model_5 & & & & \\
\hline
\end{tabular}

Source: Author's calculation, Notes: ${ }^{*} \mathrm{p}<0.05 ; * * \mathrm{p}<0.01 ; * * * \mathrm{p}<0.001$ 